\title{
PENGGUNAAN BAKTERI PROBIOTIK Alteromonas sp. BY-9 DALAM PEMELIHARAAN LARVA UDANG MELALUI PAKAN ALAMI DAN BUATAN
}

\author{
Haryanti"), Gusti Ngurah Permana*), Sari Budi Moria*), Nyoman Adiasmara Giri"), dan Ketut Sugama*)
} \begin{abstract}
ABSTRAK
Upaya untuk menyederhanakan dan mengefisiensikan penggunaan bakteri strain Alteromonas sp. BY-9 melalui pakan alami maupun pakan buatan telah dilakukan. Dalam penelitian ini strain Alteromonas sp. BY-9 dibiakkan bersama dengan mikroalga (Chaetoceros ceratosporum), sehingga terjadi penempelan sel bakteri pada dinding sel mikroalga (A), dan mencampurkan strain Alteromonas sp. BY-9 yang telah dikeringkan dengan pengeringan dingin (freeze dryed) dalam pakan buatan mikroenkapsulasi (B). Sebagai kontrol digunakan biakan sel segar Alteromonas sp. BY-9 (C) dalam pemeliharaan larva udang. Inokulasi strain Alteromonas sp. BY9 pada masing-masing perlakuan sebanyak $10^{6} \mathrm{cfu} / \mathrm{mL}$. Tiap perlakuan diulang 4 kali. Hasil yang diperolah menunjukkan bahwa sintasan larva pada $P L-10$ menunjukkan perbedaan $(P<0,05)$. Sintasan tertinggi diperoleh pada perlakuan penggunaan sel Alteromonas sp. BY-9 segar $(48,98 \%)$ diikuti dengan aplikasi Alteromonas sp. BY-9 dalam pakan alami $(40,44 \%)$; sedangkan aplikasi dalam pakan buatan hanya mendapatkan sintasan 33,70\%. Perkembangan benih antara penggunaan strain Alteromonas sp. BY-9 dalam pakan alami dan penggunaan sel segar menunjukkan 1 hari lebih cepat bila dibandingkan dengan aplikasi pakan buatan. Dari hasil uji produk ekstra seluler (ECP) dan keragaan berat molekul DNA dari strain Alteromonas sp. BY-9 yang telah diperlakukan pada masing-masing perlakuan, ternyata tidak ada perubahan berat molekul DNA. Dengan demikian peran dan kemampuan bakteri probiotik Alteromonas sp. BY-9 disinyalir juga tidak ada penurunan.
\end{abstract}

ABSTRACT: Use of Alteromonas sp. BY-9 in microalgae and artificial feed for larval rear. ing of Penaeus monodon. By: Haryanti, Gusti Ngurah Permana, Sari Budi Moria, Nyoman Adiasmara Giri, and Ketut Sugama

This experiment aimed to make more efficiently and simply in the use of probiotic Alteromonas $s p$. BY-9 for rearing of Penaeus monodon shrimp larvae. In this experiment, three treatments were tested i.e. inoculated of Alteromonas sp. BY-9 in axenic clone culture of microalgae Chaetoceros ceratosporum (A), inoculation of lyophilized form of Alteromonas sp. BY-9 in microencapsulated diet (B), and inoculation of fresh cells culture of Alteromonas sp. BY-9 as control (C). Each treatment had 4 replications and density of bacterium inoculated in larval rearing was $10^{6} \mathrm{cfu} / \mathrm{mL}$. Result showed that survival rate (SR) of fry at postlarvae-10 stage were significantly different among treatments $(P<0.05)$. The highest survival rates (48.98\%) was obtained on the use of fresh cell culture of Alteromonas sp. BY-9, followed by inoculation of Alteromonas sp. BY-9 in microalgae and microencapsulated diet with SR of $40.44 \%$ and $33.70 \%$ respectively. Growth rates of larvae between control and inoculated of Alteromonas sp. BY-9 in microalgae treatments were not significantly different, but development rate on inoculation of Alteromonas sp. BY-9 in microencapsulated diet was 1 day slower than the other treatments. Result of enzymatic activity of Extra Celluler Product (ECP) and genome DNA analyses of Alteromonas sp. BY-9 after treated by different methods did not show any differences among treatments, meaning that ability of Alteromonas sp. BY-9 as biocontrol as well as probiotics after preserved did not change.

KEYWORDS: Alteromonas BY-9, microalgae, artificial feed, shrimp larvae

\section{PENDAHULUAN}

Program pengembangan budi daya udang yang dikenal dengan Pengembangan Udang Nasional merupakan cerminan dari masih tingginya komoditas udang sebagai andalan di sektor perikanan. Menurut Ditjenkan (1999), diperkirakan pengembang-an areal pertambakan akan mencapai 380.000 ha hingga tahun 2003 dengan kebutuhan benih udang sekitar 55 milyar per tahun. Untuk memenuhi kebutuhan tersebut diperlukan upaya untuk mengantisipasi faktor-faktor kegagalan produksi di hatcheri, terutama terhadap serangan penyakit pada larva udang.

Penggunaan bahan obat-obatan, antibiotik, atau bahan kimia lainnya banyak diaplikasikan dalam

Peneliti pada Balai Besar Riset Perikanan Budidaya Laut, Gondol

-) Pusat Riset Perikanan Budidaya 
produksi benih udang untuk antisipasi serangan penyakit di hatcheri. Namun hasil yang diperoleh seringkali masih tetap di bawah perkiraan jumlah yang ditargetkan atau bahkan terjadi mortalitas massal. Upaya pengembangan bakteri sebagai probiotik maupun kontrol biologi dalam usaha pembenihan ikan, krustase, dan kekerangan telah banyak dikembangkan.

Hasil yang diperoleh dari Balai Besar Riset Perikanan Budidaya Laut, Gondol-Bali, menunjukkan bahwa strain bakteri Alteromonas sp. BY-9 telah dapat diaplikasikan sebagai probiotik dan kontrol biologi dalam pemeliharaan larva udang windu Penaeus monodon. Dari beberapa penelitian yang telah dilakukan menunjukkan bahwa pemanfaatan bakteri Alteromonas sp. BY-9 dapat meningkatkan sintasan hingga mencapai $30 \%-60 \%$, pertumbuhan yang lebih cepat dan mutu benur yang lebih baik serta dapat menekan penyakit Vibrio patogen (Luminescent vibriosis) hingga populasi sangat rendah atau bahkan tidak ada dalam media pemeliharaan larva maupun dalam tubuh udang (Haryanti et al., 1997a; Haryanti et al., 1997b; Haryanti et al., 1998; Haryanti \& Sugama, 1998).

Upaya untuk menyederhanakan dan mengefisiensikan penggunaan bakteri probiotik Alteromonas sp. BY-9 dalam pemeliharaan larva telah dicoba melalui pakan alami dan buatan agar memudahkan dalam penanganan dan penggunaannya, tanpa mengurangi kemampuan bakteri dalam melakukan perannya. Dengan mengembangbiakkan bakteri Alteromonas sp. BY-9 dalam biakan mikroalga, $C$. ceratosporum diharapkan akan lebih efisien dalam penyediaan bakteri probiotik dalam pemeliharaan larva, karena hanya dengan mengkultur mikroalga sekaligus bakteri Alteromonas sp. BY-9 sudah ikut berkembang biak pula. Menempelnya bakteri Alteromonas sp. BY-9 pada dinding sel mikroalga juga akan menguntungkan bagi larva, karena sel bakteri akan ikut tercerna, sehingga akan meningkatkan kecernaan larva udang. Beberapa ahli juga berpendapat bahwa pertumbuhan mikroalga dapat distimulasi dengan adanya koeksistensi strain bakteri yang diinokulasikan dalam kulturnya (Fukami et al., 1992; Haryanti, 1997; Requelm et al., 1988; Sukoso et al., 1998).

Dalam hubungannya dengan pakan buatan, Fuller (1986) dan Uma (1999) menjelaskan bahwa bakteri probiotik sebagai suplemen pakan memiliki pengaruh menguntungkan untuk memperbaiki keseimbangan mikroflora pada saluran pencernaan larva. Mekanisme aktivitas dari probiotik yaitu (a) menekan pertumbuhan bakteri melalui produksi senyawa antimikrobial, kompetisi nutrien, dan kompetisi sisi pengikatan, (b) mengubah keseimbangan metabolisme mikrobial dengan meningkatkan dan menurunkan aktivitas enzim dan, (c) stimulasi immunitas dengan meningkatkan antibodi dan aktivitas macrophage. Dengan demikian penambahan bakteri probiotik dalam pakan buatan perlu diuji karena pertimbangan fenomena di atas, sehingga diharapkan dapat diperoleh teknik penggunaan bakteri probiotik yang efektif, baik melalui pakan alami maupun pakan buatan, dan akhirnya dapat berdampak terhadap peningkatan produksi benih udang.

\section{BAHAN DAN METODE}

\section{Kultur bakteri Alteromonas sp. BY-9}

Bakteri Alteromonas sp. BY-9 dikembangbiakkan dengan mengikuti metode Nogami \& Maeda (1992). Media kultur bakteri probiotik mengandung campuran antara bacto peptone, bacto malt-extract, bacto yeastextract, dan bacto soytone dengan kadar masingmasing $0,05 \% ; 0,1 \% ; 0,05 \%$; dan $0,1 \%$ dalam air laut steril dengan $\mathrm{pH} 7,6$ dan suhu $25^{\circ} \mathrm{C}$.

Isolat Alteromonas sp. BY-9 yang dibiakkan dalam media agar miring disuspensikan dalam $10 \mathrm{~mL}$. air laut steril dengan jarum ose. Suspensi bakteri tersebut kemudian diinokulasikan lebih lanjut sebanyak $2,5 \mathrm{~mL}$ ke dalam $50 \mathrm{~mL}$ media tumbuh baru dan diinkubasikan selama 48 jam dalam $25^{\circ} \mathrm{C}$. Bakteri yang telah tumbuh dalam volume ini merupakan inokulan bagi media biakan berikutnya dengan volume yang lebih besar.

Untuk mendapatkan biakan bakteri dengan volume $5 \mathrm{~L}$. diperlukan inokulan bakteri sebanyak $10 \mathrm{~mL}$ dan diinkubasi selama 48 jam pada suhu $25^{\circ} \mathrm{C}$. Selama inkubasi juga ditambahkan aerasi yang telah melalui filter $0,20 \mathrm{~mm}$. Dari volume tersebut biakan Alteromonas sp. BY-9 sudah dapat digunakan untuk inokulasi dalam media pemeliharaan larva udang dan inokulasi pada biakan mikroalga C. ceratosporum.

\section{Inokulasi bakteri Alteromonas sp. BY-9 dalam biakan mikroalga (C. ceratosporum)}

Mikroalga yang dibiakkan bersama dengan Alteromonas sp. BY-9 adalah C. ceratosporum dari hasil axenic clone culture (biakan sel tunggal yang bebas dari kontaminasi bakteri) sehingga merupakan mikroalga yang bebas bakteri. Untuk membiakkan mikroalga tersebut digunakan pupuk $\mathrm{KNO}_{3}, \mathrm{NaHPO}_{4}$ $2 \mathrm{H}_{2} \mathrm{O}$, Fe EDTA, Clewat-32, $\mathrm{Na}_{2} \mathrm{SiO}$, dan Vitamin mix dengan konsentrasi masing-masing sebesar $50 ; 4$; 2,$5 ; 5 ; 50$; dan $0,01 \mathrm{mg} / \mathrm{L}$. Media biakan disiapkan dengan sterilisasi basah pada suhu $115^{\circ} \mathrm{C}$ selama 30 menit dan inokulasinya dilakukan secara aseptik di dalam clean banch. Biakan dimulai dari volume 10 $\mathrm{mL}$ dalam tabung-tabung reaksi dan diperbesar hingga $100-200 \mathrm{~mL}$. 
Bakteri Alteromonas sp. BY-9 diinokulasikan ke dalam biakan C. ceratosporum pada volume 100-200 $\mathrm{mL}$ pada fase stationer, sebanyak $10^{6} \mathrm{cfu} / \mathrm{mL}$ dan kemudian mikroalga ini dikembangbiakkan hingga mencapai volume 30 liter. Pada perkembangbiakan skala laboratoris ini dilakukan pada suhu $23-25^{\circ} \mathrm{C}$, penyinaran 4.500 lux dan pemberian aerasi yang telah melalui sistem penyaringan $0,20 \mathrm{~mm}$. Media tumbuh mikroalga pada volume besar tersebut juga ditambahkan media tumbuh bakteri dengan dosis rendah. Biakan mikroalga sudah dapat digunakan dalam pemeliharaan larva setelah mencapai kepadatan sel tertinggi dalam 3-4 hari.

\section{Inokulasi bakteri Alteromonas sp. BY-9} dalam pakan buatan mikroenkapsulasi

Untuk mendapatkan bakteri Alteromonas sp. BY9 kering yang akan dicampurkan dalam pakan buatan mikroenkapsulasi, dilakukan dengan membiakkan bakteri tersebut dalam volume 5-10 L hingga mencapai kepadatan $10^{10}-10^{11} \mathrm{cfu} / \mathrm{mL}$ dan disentrifuse pada kecepatan $8.000 \mathrm{rpm}$, pada suhu $4^{\circ} \mathrm{C}$ selama 10 menit. Hasil yang diperoleh disimpan terlebih dahulu pada $-85^{\circ} \mathrm{C}$ dengan menambahkan larutan antifreezing yang mengandung gliserol $10 \%$ dan selanjutnya dikeringkan dengan menggunakan pengeringan dingin (freeze dryer). Bobot kering bakteri Alteromonas sp. BY-9 yang dicampurkan dalam pakan mikroenkapsulasi diperhitungkan kepadatannya agar menjadi $10^{6} \mathrm{cfu} / \mathrm{mg}$ pakan. Dalam proses pembuatan pakan buatan tersebut juga dipertimbangkan suhu pemanasan, maksimal sebesar $38^{\circ} \mathrm{C}-40^{\circ} \mathrm{C}$, karena bakteri Alteromonas sp. BY-9 hanya dapat bertahan hidup pada suhu di bawah suhu tersebut. Metode pembuatan pakan buatan mikroenkapsulasi mengikuti metode Giri et al. (1992).

\section{Pemeliharaan larva}

Nauplii hasil penetasan telur dari induk matang gonad yang dirangsang dengan ablasi tangkai mata, didesinfeksi dengan $100 \mathrm{mg} / \mathrm{L}$ iodin selama 10 menit. Wadah yang digunakan dalam penelitian ini adaiah bak polikarbonat volume $1.000 \mathrm{~L}$ sebanyak 12 bak. Padat penebaran awal larva (nauplii) adalah 75 ekor/L. Metode pemeliharaan larva sesuai dengan Haryanti et al. (1997a). Larva dipelihara hingga stadia pascalarva-10. Selama penelitian larva diberi pakan alami C. ceratosporum dengan kepadatan awal 5.000 $\mathrm{sel} / \mathrm{mL}$ dan secara bertahap ditingkatkan hingga $40.000 \mathrm{sel} / \mathrm{mL}$ serta pakan buatan komersial. Pada stadia postlarva diberikan Artemia salina dengan kepadatan 5 nauplii artemia per ekor dan terus meningkat hingga mencapai postlarva 10.

Dalam penelitian ini diterapkan 3 perlakuan yaitu: (A) inokulasi bakteri Alteromonas sp. BY-9 pada biakan axenic clone dari C. ceratosporum, (B) inokulasi bakteri Alteromonas sp. BY-9 kering (freeze dryer) ke dalam pakan mikroenkapsulasi, dan (C) inokulasi biakan segar bakteri Alteromonas sp. BY-9 (kontrol) ke dalam pemeliharaan larva udang. Biakan bakteri yang diinokulasikan dalam media pemeliharaan larva udang sebanyak $10^{6} \mathrm{cfu} / \mathrm{mL}$. Masing-masing perlakuan diulang 4 kali. Peubah biologis yang diamati adalah sintasan larva setiap stadia, pertumbuhan, jumlah total bakteri dan vibrio dalam air pemeliharaan larva, dan kualitas air.

\section{Uji vitalitas}

Vitalitas benih PL-10 dari masing-masing perlakuan diuji secara fisik yaitu dengan pengeringan di atas kertas saring selama 5 dan 10 menit, sedangkan secara kimiawi dengan perendaman larutan formaldehide ( $37 \%$ kandungan aktif) pada konsentrasi sebesar 100 dan $150 \mathrm{mg} / \mathrm{L}$ selama 15 menit. Pengujian dilakukan dengan menggunakan wadah gelas becker volume $1 \mathrm{~L}$ yang diisi air laut, dilengkapi dengan aerasi dan padat tebar sebanyak 30 ekor per wadah.

Pada uji pengeringan, benih dikembalikan dalam gelas becker yang berisi air laut setelah waktu uji tercapai dan diamati tingkat kematian atau stress masing-masing perlakuan. Hal yang sama juga dilakukan pada perlakuan uji formaldehide.

\section{Pengujian aktivitas enzimatik dari Extra Celluler Product (ECP) bakteri Alteromonas sp. BY-9}

Aktivitas enzimatik Alteromonas sp. BY-9 yang telah mendapatkan perlakuan yang berbeda diuji melalui produk ekstra selulernya (ECP) untuk mengetahui kemampuan bakteri sebagai probiotik dan kontrol biologi. Pengujian mengikuti metode Xu Bing et al. (1996), yaitu dengan menggunakan teknik cellophane plate. Lembaran cellophane steril diletakkan pada permukaan marine agar (mengandung $1 \%$ bacto peptone; $0,3 \%$ beef extract; $0,2 \%$ yeast extract; $0,01 \% \mathrm{FePO}_{4}$ dan $1,5 \%$ agar; $\mathrm{pH} 7,5$ ) dalam cawan petri dan diinokulasikan $200 \mathrm{~mL}$ biakan Alteromonas sp. BY-9 yang telah diperlakukan sesuai dengan masing-masing perlakuan. Lama inkubasi 24 jam pada suhu $25^{\circ} \mathrm{C}$. Bakteri yang tumbuh pada permukaan cellophane selanjutnya dicuci dengan $4 \mathrm{~mL}$ larutan penyangga fosfat (Phosphate Buffer Solution/PBS) $0,01 \mathrm{M}$ dan $\mathrm{pH} 7,0$. Suspensi bakteri disentrifuge dengan kecepatan 8.000 rpm selama 15 menit pada suhu $4^{\circ} \mathrm{C}$ dan supernatan yang diperoleh disaring secara steril dengan saringan membran $0,20 \mathrm{~mm}$.

Pengujian aktivitas enzimatik dari ECP dilakukan dengan menggunakan teknik cylinder plate. Media agar $(2 \% \mathrm{w} / \mathrm{v})$ yang masing-masing mengandung $0,4 \%$ gelatin; $0,4 \%$ kasein; $0,2 \%$ starch; $2,5 \%$ egg yolk; 
1,0\% Tween $80 ; 2,0 \%$ urea; dan 2,0\% phenol red dengan $\mathrm{pH} 7,5$ disiapkan dalam cawan petri, yaitu untuk menguji adanya aktivitas enzim gelatinase, kasease, amilase, lesitinase, lipase, urease, dan kitinase.

Larutan produk extra seluler (ECP) ditambahkan dalam pipa polyetheline berbentuk silinder (nalgene pipe) yang diletakkan di atas permukaan media agar dan diinkubasi pada suhu $35^{\circ} \mathrm{C}$ selama 48 jam. Pengamatan aktivitas enzym dilakukan dengan menambahkan $5 \% \mathrm{HgCl}_{2}$ pada agar gelatin, $10 \%$ asam trikloroasetat pada agar kasein, lugol iodin pada agar starch serta pengamatan perubahan zone pada media agar.

\section{Pola pita DNA bakteri Alteromonas sp. BY-9 melalui amplifikasi PCR dan restriksi panjang fragmen polimorfisme}

Alteromonas sp. BY-9 yang ada dalam masingmasing perlakuan (mikroalga, pakan mikroenkapsulasi, dan biakan segar) diisolasi dan dipurifikasi kembali untuk dianalisis keragaan DNAnya dengan mengernbangbiakkan dan memanen dari $200 \mathrm{~mL}$ biakan bakteri melalui sentrifugasi. Konsentrat bakteri dilarutkan dalam $4,75 \mathrm{~mL}$ TE buffer $(10 \mathrm{mM}$ Tris-Cl dan 1 mM EDTA-2Na, pH 8,0) dan ditambahkan $250 \mathrm{~mL}$ Sodium Dedocyl Sulfat (SDS) $10 \%$ serta 25 $\mathrm{ml}$ Proteinase Kinase $(20 \mathrm{mg} / \mathrm{mL})$. Suspensi ini diinkubasi selama 60 menit pada suhu $37^{\circ} \mathrm{C}$. Kemudian lysate ditambahkan $5 \mathrm{M} \mathrm{NaCl}$ sebanyak 900 $\mathrm{ml}$ dan $750 \mathrm{~mL}$ CTAB-NaCl (10\% CTAB dan 0,7 M $\mathrm{NaCl})$ dan diinkubasi pada $65^{\circ} \mathrm{C}$ selama 20 menit. Setelah deproteinisasi dengan kloroform dan isoamil alkohol serta hidrolisis enzimatik dengan RNAse, genome DNA dilarutkan dalam $300 \mathrm{~mL}$ TE buffer dan disimpan pada suhu $-20^{\circ} \mathrm{C}$.

Amplifikasi PCR terhadap genome DNA bakteri Alteromonas sp. BY-9 dari masing-masing perlakuan dilakukan dengan mencampurkan beberapa reagent (10x PCR buffer, $20 \mathrm{mM}$ dNTPs mix; $2 \mathrm{mM} \mathrm{MgCL}$; 100 pikomol primer $27 \mathrm{f}$ dan 1492 r; 0,5 Unit taq polimerase dan akuades) dalam mikrotube (200 uL) dan diinkubasi dalam mesin PCR (Takara Biomedikals) dengan 35 cycles. Dalam amplifikasi ini digunakan suhu denaturasi $94^{\circ} \mathrm{C}$ selama 1 menit, suhu annealing $60^{\circ} \mathrm{C}$ selama 1 menit dan suhu ekstention $72^{\circ} \mathrm{C}$ selama 3 menit. Untuk mengetahui keragaan fragmen DNA yang telah diamplifikasi, maka digunakan 1,5\% agarose gel elektroforesis dalam 1\% TAE buffer (Tris Asetat EDTA) selama 30 menit. Sebagai molekuler maker digunakan DNA ladder 100 bp dan IHIND III, sedangkan untuk staining digunakan ethidium bromide dengan cara perendaman selama 20 menit.
Untuk mengetahui panjang fragmen polimorfismenya, template DNA produk amplifikasi PCR dipurifikasi kembali dan dipotong dengan restriksi enzim Mbol, Hae III, dan Hhal. Dengan menggunakan $4 \%$ agarose gel dan elektrophoresis selama 30 menit serta pewarnaan dengan etidium bromide, maka akan dapat diperoleh potongan panjang fragmen dari masing-masing template DNA. Sebagai molekuler maker digunakan DNA ladder 100 bp sedangkan untuk kontrol digunakan template DNA yang tidak mengalami pemotongan.

\section{HASIL DAN BAHASAN}

\section{Kultur bakteri Alteromonas sp. BY-9}

Dari hasil pengembangbiakan bakteri Alteromonas sp. BY-9 pada volume besar $(5 \mathrm{~L})$ ternyata kepadatan sel terting gi mencapai $3-5 \times 10^{11} \mathrm{cfu} / \mathrm{mL}$, sedangkan pada volume $50 \mathrm{~mL}$, kepadatan sel yang diperoleh lebih rendah hanya $2 \times 10^{\circ} \mathrm{cfu} / \mathrm{mL}$. Hal ini berhubungan dengan adanya aerasi yang ditambahkan selama pembiakan, sehingga proses perkembangbiakan sel lebih cepat, walaupun sifat dari bakteri BY-9 fakultatif oksidatif, namun oksigen akan memacu dalam pembelahan sel dan metabolisme.

\section{Inokulasi bakteri Alteromonas sp. BY-9 dalam biakan mikroalga (C. ceratosporum)}

Inokulasi Alteromonas sp. BY-9 dengan kepadatan $10^{6} \mathrm{cfu} / \mathrm{mL}$ dalam biakan mikroalga dari axenic clone culture pada volume 100-200 mL dalam fase stationer menunjukkan hasil yang positif, baik terhadap pertumbuhan sel mikroalga ataupun sel bakteri hingga dikultur dalam volume $30 \mathrm{~L}$. Hal ini terlihat dari pemantauan pertumbuhan sel bakteri dan mikroalga yang tertera pada Gambar 1. Sel Alteromonas sp. BY-9 selain hidup dalam media biakan mikroalga juga menempel pada dinding sel mikroalga, sehingga pembelahan sel mikroalga akan diikuti oleh penempelan bakteri secara terus-menerus.

\section{Inokulasi bakteri Alteromonas sp. BY 9 dalam pakan mikroenkapsulasi}

Hasil yang diperoleh dari pengeringan beku (freeze dried) dari $5 \mathrm{~L}$ bakteri Alteromonas sp. BY-9 hanya diperoleh $4,3 \mathrm{~g}$ bobot kering. Dengan menambahkan $10^{6} \mathrm{cfu}$ per mg pakan maka dapat diperhitungkan kebutuhan pakan dan bakteri kering selama penelitian. Untuk mengkonfirmasi keberadaan Alteromonas sp. BY-9, dilakukan pengkulturan kembali pakan mikroenkapsulasi dalam air laut steril dengan pemberian aerasi dan diinkubasi selama 24-48 jam. Ternyata dalam 1 $\mathrm{mg}$ pakan hanya diperoleh bakteri Alteromonas sp. 


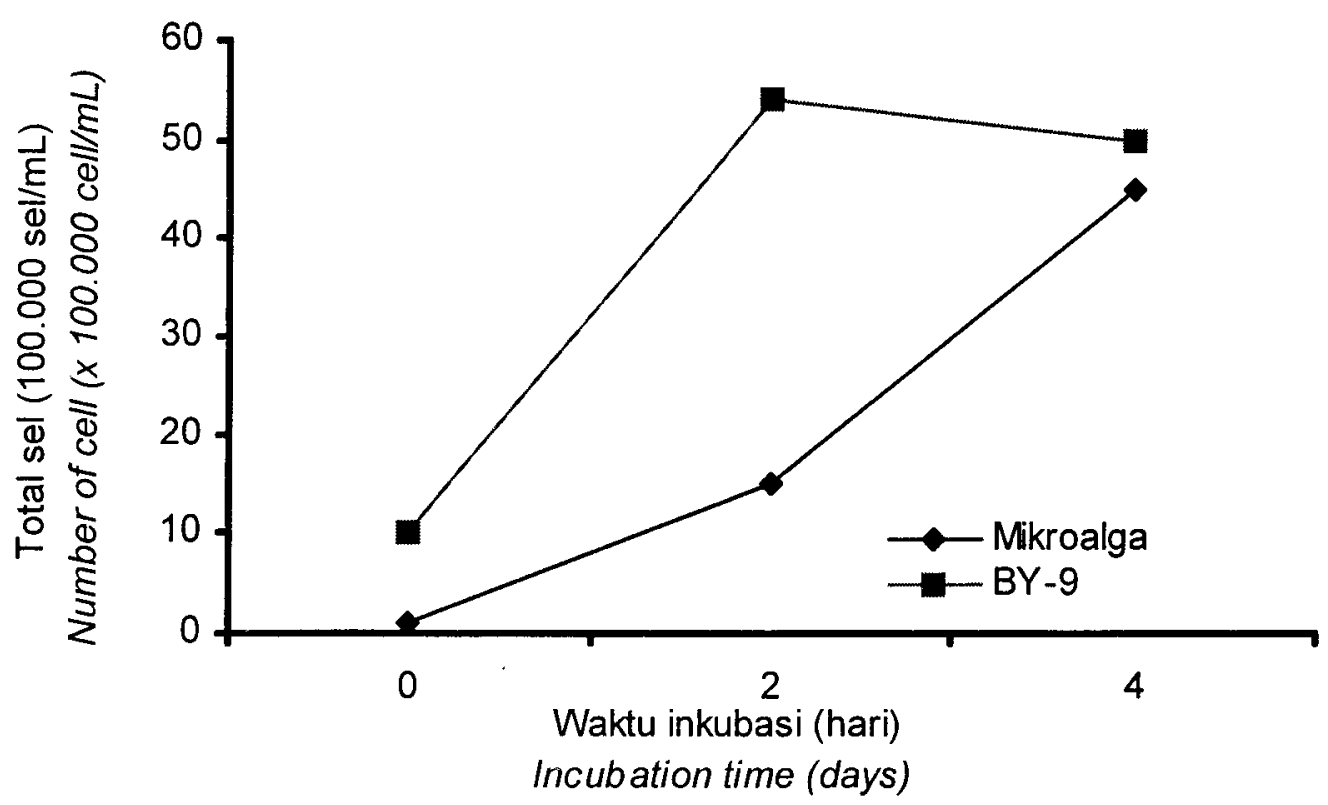

Gambar 1. Kepadatan bakteri Alteromonas sp. BY-9 dan C. ceratosporum dalam wadah pemeliharaan mikroalga Figure 1. Density of Alteromonas sp. BY-9 and C. ceratosporum in the culture tank

BY- 9 sebanyak $5,4 \times 10^{3} \mathrm{cfu} / \mathrm{mL}$ pada 24 jam pertama dan meningkat $3 \times 10^{4} \mathrm{cfu} / \mathrm{mL}$ pada waktu 48 jam. Jumlah ini sangat berkurang bila dibandingkan dengan awal inokulasi dalam pakan $\left(10^{6} \mathrm{cfu} / \mathrm{mg}\right)$. Kemungkinan sel bakteri mengalami kematian pada waktu proses pembuatan pakan mikroenkapsulasi yang memerlukan pemanasan untuk pengikatan molekulnya.

\section{Pemeliharaan larva}

Hasil yang diperoleh dalam penelitian ini menunjukkan bahwa inokulasi Alteromonas sp. BY9 dalam biakan $C$. ceratosporum dan pakan buatan mikroenkapsulasi memberikan sintasan yang berbeda $(P<0,05)$ bila dibandingkan dengan kontrol. Sintasan larva yang diinokulasi bakteri Alteromonas sp. BY-9 dengan perlakuan yang berbeda terlihat pada Gambar 2. Hal ini menunjukkan bahwa sintasan tertinggi $(48,98 \%)$ diperoleh pada inokulasi Alteromonas $\mathrm{sp}$. BY-9 dalam biakan segar, dan berbeda nyata $(P<0,05)$ dibandingkan dengan inokulasi Alteromonas sp. BY-9 dalam pakan alami $C$. ceratosporum $(40,44 \%)$ dan pakan buatan mikroenkapsulasi $(33,70 \%)$.

Mortalitas larva pada perlakuan inokulasi Alteromonas sp. BY-9 dalam pakan alami (mikroalga) dan inokulasi dalam bentuk biakan segar, terjadi secara perlahan-lahan dari sejak stadia zoea hingga pascalarva, sedangkan pada perlakuan inokulasi bakteri pada pakan mikroenkapsulasi, mortalitas

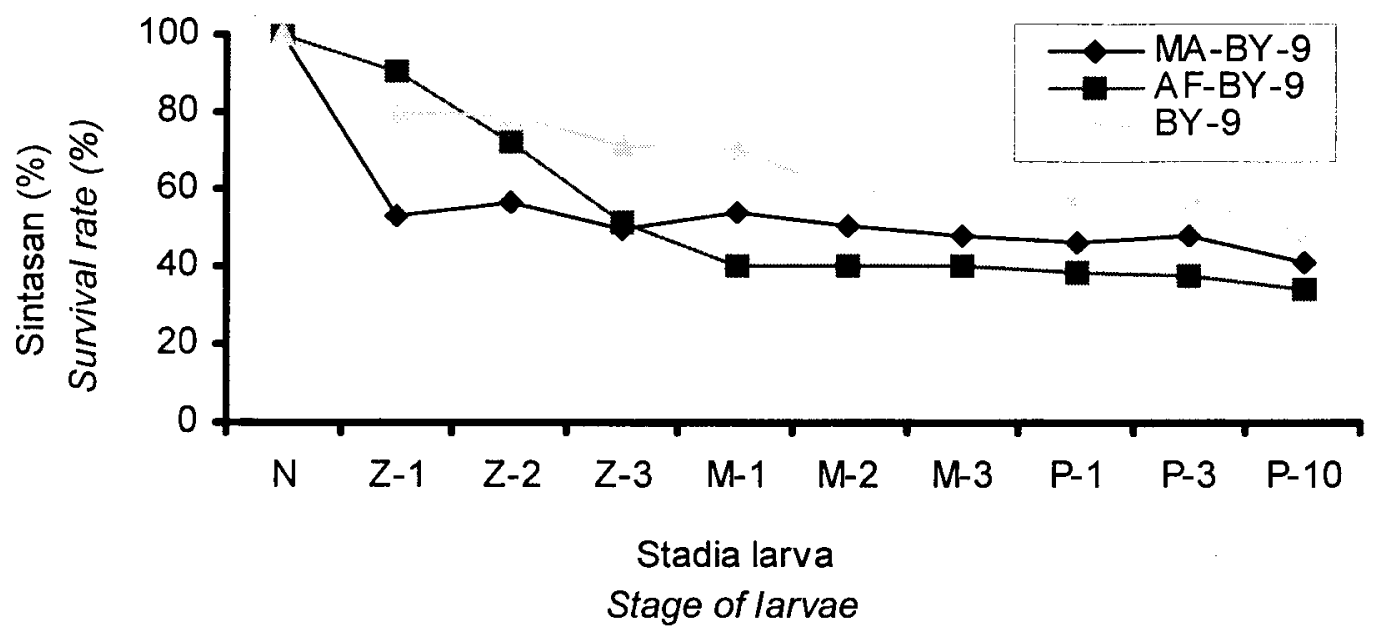

Gambar 2. Sintasan larva P. monodon yang diinokulasi Alteromonas sp. BY-9 dengan perbedaan perlakuan Figure 2. Survival rate of $P$. monodon larvae reared with different treatment inoculation of Alteromonas $s p$. BY-9 
secara cepat terjadi sejak stadia zoea-3 hingga mysis dan berlanjut hingga pascalarva

Hasil dari pengamatan pertumbuhan larva udang, terlihat bahwa larva yang dipelihara dengan menginokulasi bakteri Alteromonas sp. BY-9 dalam mikroalga dan biakan segar ternyata tidak berbeda nyata, yaitu diperlukan 9 hari hingga mencapai stadia pasca larva1, sedangkan inokulasi Alteromonas sp. BY-9 dalam pakan mikroenkapsulasi terlambat 24--36 jam yang dimulai sejak perubahan stadia zoea-3 menjadi mysis1 dan berlanjut hingga pascalarva-1, seperti tersaji pada Gambar 3. Pengamatan kualitas air pemeliharaan larva menunjukkan hasil yang berada pada kisaran yang masih dapat ditoleransi dan layak untuk sintasan larva. Kisaran nilai suhu antara $27,0^{\circ} \mathrm{C}--27,5^{\circ} \mathrm{C}$ (pagi) dan $28,5^{\circ} \mathrm{C}--28,9^{\circ} \mathrm{C}$ (sore); nilai pH antara $8,10--8,25$ (pagi) dan 8,20--8,31 (sore); dan salinitas 34--35 ppt.

Hasil dari pengamatan populasi total bakteri, vibrio, dan keberadaan bakteri Alteromonas sp. BY-9 dalam (inokulasi bakteri Alteromonas sp. BY-9 dalam pakan alami) dan perlakuan B (inokulasi Alteromonas sp. BY-9 dalam pakan buatan mikroenkapsulasi) relatif lebih tinggi $4 \times 10^{2}$ dan $4-8 \times 10^{2} \mathrm{cfu} / \mathrm{mL}$ bila dibandingkan dengan kontrol (inokulasi Alteromonas sp. BY-9 dalam bentuk sel segar), $2 \times 10^{2} \mathrm{cfu} / \mathrm{mL}$. Bila dilihat dari keberadaan sel bakteri Alteromonas sp. BY-9 dalam media pemeliharaan larva, terlihat bahwa sel bakteri Alteromonas sp. BY-9 dalam perlakuan $\mathrm{C}$ lebih tinggi populasinya $\left(6-8 \times 10^{3} \mathrm{cfu} /\right.$ $\mathrm{mL})$ bila dibandingkan dengan perlakuan $A\left(4 \times 10^{3}\right.$ $\mathrm{cfu} / \mathrm{mL})$ dan $B\left(2 \times 10^{3} \mathrm{cfu} / \mathrm{mL}\right)$. Hal ini menunjukkan adanya korelasi positif antara jumlah sel bakteri Alteromonas sp. BY-9 yang cukup kepadatannya dalam media pemeliharaan larva akan melakukan fungsinya sebagai kontrol biologi yaitu menekan pertumbuhan vibrio atau bakteri oportunistik patogen lainnya serta peran probiotik. Hasil yang diperoleh Moriarty 1998, juga menunjukkan bahwa dengan penambahan Bacillus antara $1 \times 10^{4}$ hingga $1 \times 10^{5} \mathrm{cfu}$
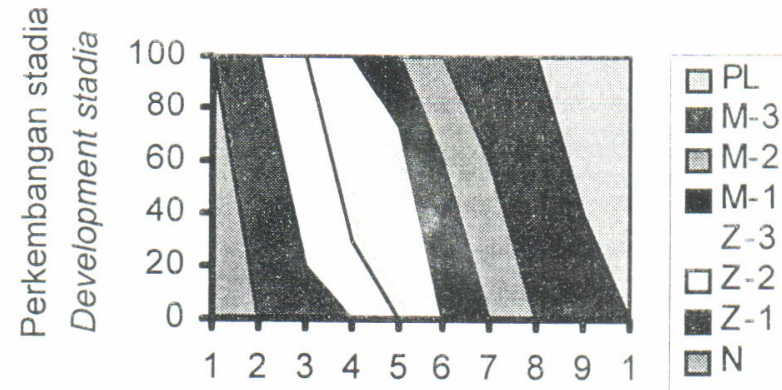

Hari (Days)
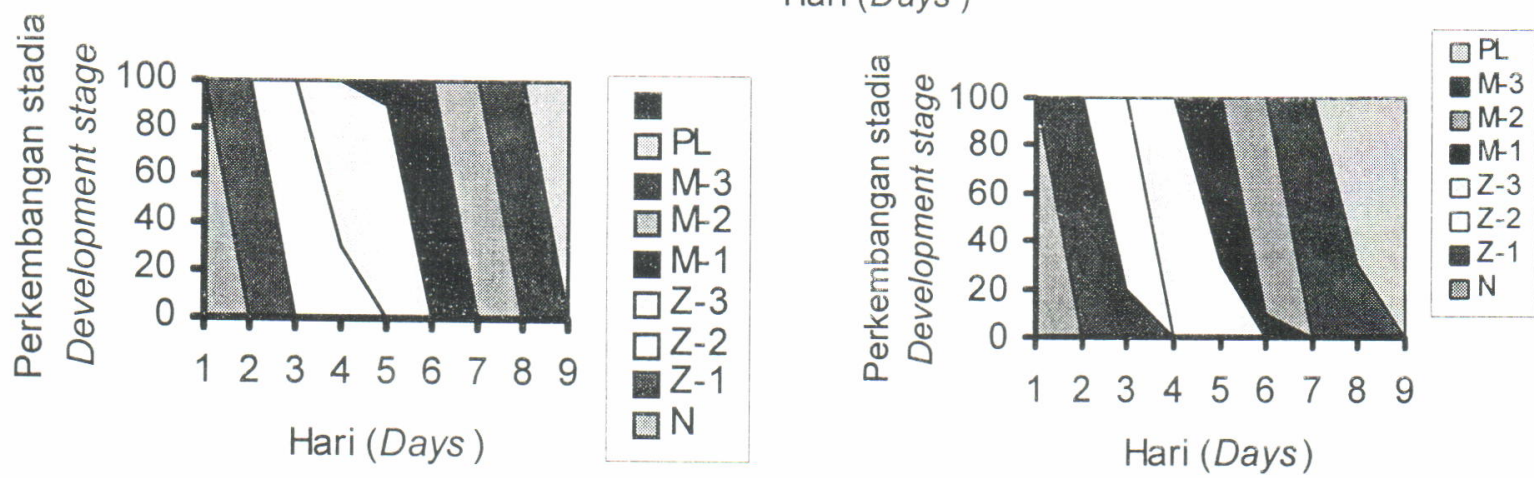

Gambar 3. Perkembangan stadia larva $P$. monodon yang diinokulasikan bakteri Alteromonas sp. BY-9 dengan perlakuan yang berbeda (A: Alteromonas sp. BY-9 dalam mikroalgae; B: Alteromonas sp. BY-9 dalam pakan buatan; C: Alteromonas sp. BY-9 segar)

Figure 3. Development stage of shrimp larvae of $P$. monodon with different treatment inoculation of Alteromonas sp. BY-9 (A: Alteromonas sp. BY-9 in microalgae; B: Alteromonas sp. BY-9 in artificial feed; C: Alteromonas sp. BY-9 fresh form)

media pemeliharaan larva yang mendapat perlakuan berbeda tertera pada Gambar 4. Nampaknya total bakteri dalam media pemeliharaan larva antar perlakuan tidak berbeda kepadatannya, yaitu berkisar $10^{2}-10^{4} \mathrm{cfu} / \mathrm{mL}$. Namun populasi vibrio menunjukkan perbedaan antar perlakuan, yaitu pada perlakuan $A$
$\mathrm{mL}$ dapat menekan populasi luminous Vibrio dan meningkatkan produksi udang serta mempertahankan kolom air yang lebih baik.

Adanya perbedaan sintasan dan pertumbuhan larva dari ketiga perlakuan tersebut dimungkinkan karena 

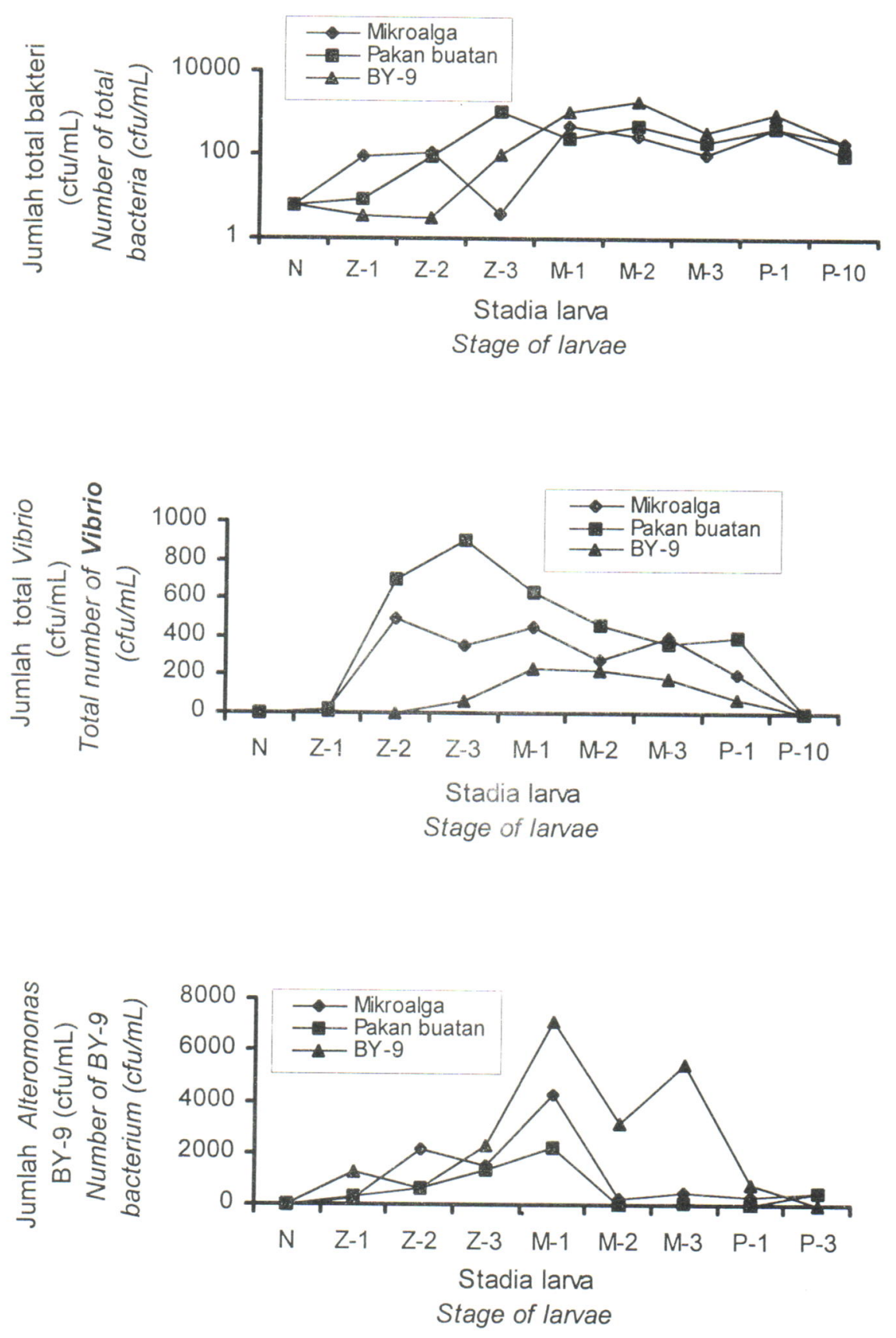

Gambar 4. Pola pertumbuhan total bakteri, Vibrio, dan Alteromonas sp. BY-9 dalam wadah pemeliharaan larva yang diinokulasi bakteri Alteromonas sp. BY-9 dengan perlakuan berbeda

Figure 4. Growth pattern of total bacteria, Vibrio, and Alteromonas sp. BY-9 in the rearing tank with different treatment inoculation of Alteromonas $s p$. BY-9

bakteri Alteromonas sp. BY-9 yang ditambahkan memerankan kemampuannya dalam penekanan populasi Vibrio patogen maupun bakteri oportunistik patogen, yaitu dengan mengeluarkan senyawa semacam antibakterial, sehingga selama pemeliharaan jumlah Vibrio sangat rendah populasinya. Efek antibakterial dari bakteri pada umumnya disebabkan oleh kombinasi beberapa faktor yaitu produksi antibiotik, bacteriocins, siderospore, lysozyme, protease, dan pelepasan nilai $\mathrm{pH}$ yang menghasilkan asam organik (Sugita et al., 1998). Pendapat yang dikemukakan oleh Nakamura et al. (1999) menunjukkan bahwa mekanisme bakteri dapat berperan sebagai agen biokontrol dalam menekan Vibrio adalah dihasilkannya senyawa vibriostatik atau vibriosidal oleh bakteri dan niche competition antara Vibrio patogen dan bakteri agen biokontrol. 
Menurut Gibson et al. (1998), bakteri probiotik Aeromonas media dapat melepaskan senyawa penghambat yang disebut Bacteriocin-like inhibitory substance pada Pasifik oyster Crassostrea gigas. Hal yang sama juga ditunjukkan oleh Douillet \& Langdon (1994) bahwa penambahan bakteri CA2 sebagai suplemen pakan pada biakan axenic larva Crassostrea gigas dengan kepadatan $10^{5} \mathrm{cfu} / \mathrm{mL}$ dapat meningkatkan pertumbuhan larva oyster. Kondisi ini disinyalir bahwa bakteri mempunyai kontribusi nutrisional terhadap pertumbuhan larva

Di samping itu diduga bahwa dengan jumlah sel yang cukup dalam media pemeliharaan larva, bakteri Alteromonas sp. BY-9 juga memperbaiki fungsi kecernaan larva udang, sehingga keragaan pertumbuhan larva relatif lebih cepat. Sementara pada perlakuan inokulasi Alteromonas sp. BY-9 dalam pakan buatan mikroenkapsulasi, jumlah sel relatif rendah yang kemungkinan disebabkan oleh proses pembuatan pakan melalui pemanasan, maka kemampuan memerankan perannya sebagai pengontrol biologis maupun probiotik menjadi menurun. Akibat lebih lanjut, keragaan sintasan dan pertumbuhan larva udang juga lebih rendah. Hasil penelitian Rengpipat et al. (1998) menunjukkan bahwa penambahan bakteri probiotik dalam pakan tidak memberikan perbedaan pertumbuhan bila dibandingkan dengan kontrol (tanpa probiotik), tetapi sintasan maupun penampakan eksternal sangat berbeda, yaitu udang lebih sehat setelah diuji tantang dengan Vibrio harveyii dengan 100\% sintasan dan tanpa perubahan tekstur hepatopankreas dan saluran pencernaan.

\section{Vitalitas benih pada PL-10}

Dari hasil uji vitalitas yang diperoleh ternyata benih yang dipelihara dengan inokulasi bakteri Alteromonas sp. BY-9 dalam pakan alami ataupun dalam pakan buatan mikroenkapsulasi dan bentuk sel segar tidak berbeda nyata dalam menerima respon pengeringan selama 5 menit di atas kertas saring, yaitu dengan tingkat stress 7\%--13\% dan sintasan masing-masing $87 \%, 80 \%$, dan $93 \%$. Namun, pada uji pengeringan 10 menit nampaknya benih tidak dapat merespon perlakuan tersebut, sehingga sintasan antara 3 perlakuan relatif rendah $(50 \%--73 \%)$, sedangkan tingkat stress juga tinggi. Dalam uji ini nampaknya perlakuan inokulasi Alteromonas sp. BY-9 dalam pakan mikroenkapsulasi dan sel segar memberikan sintasan lebih tinggi, masing-masing $73 \%$ dan $70 \%$.

Hasil uji perendaman formalin (kandungan formaldehyde $37 \%$ p.a.) ternyata dengan konsentrasi 100 $\mathrm{mg} / \mathrm{L}$ selama 15 menit, benih dapat merespon dengan baik dan sintasan yang diperoleh tidak berbeda nyata
$(P>0,05)$ antar 3 perlakuan, yaitu $87 \%$--93\% dan tingkat stress yang rendah. Sedangkan pada perendaman dengan konsentrasi $150 \mathrm{mg} / \mathrm{L}$ larva banyak mengalami stress dan diasumsikan akan mengalami kematian, sehingga sintasan relatif rendah hanya berkisar antara $67 \%--73 \%$.

Perbedaan kemampuan benih dalam merespon uji vitalitas yang diberikan mungkin berhubungan dengan perlakuan yang diterapkan selama pemeliharaan larva. Nampaknya perlakuan inokulasi bakteri Alteromonas sp. BY-9 dalam pakan buatan mikroenkapsulasi atau bentuk segar relatif memberikan kontribusi nutrisional dalam saluran pencernaannya. Walaupun masih merupakan tanda tanya hubungan efek probiont pada respon imunitas pada larva udang, namun kemungkinan ke arah tersebut masih ada peluang.

\section{Aktivitas enzimatik dari produk ekstra seluler (ECP) bakteri Alteromonas sp. BY-9}

Hasil pengujian terhadap aktivitas enzimatik dari produk ekstra seluler bakteri Alteromonas sp. BY-9 yang telah mendapatkan perlakuan yang berbeda, ternyata ada beberapa koloni pada perlakuan $A$ (inokulasi BY-9 pada pakan alami) dan B (inokulasi BY-9 pada pakan mikroenkapsulasi) menunjukkan aktivitas enzimatik yang berbeda bila dibandingkan dengan kontrol, yaitu pada aktivitas lipase, urease, dan kitinase. Hal ini mungkin disebabkan oleh sedikitnya enzim yang terekstraksi, sehingga tidak ada sintesis dalam agar, dan selanjutnya tidak terbentuk gambaran zone di sekitar pipa silinder pada agar. Sementara itu pada aktivitas enzimatik urease dan kitinase yang positif diduga adanya kontaminasi bakteri lain selama inkubasi, sehingga terbentuk gambaran zone tipis di sekitar pipa silinder nalgene pada agar.

Namun demikian perbedaan tersebut dapat dikonfirmasikan kembali secara molekuler dengan pengujian DNA melalui amplifikasi PCR dan pemotongan template DNA-nya dengan beberapa enzim rektriksi untuk mengetahui panjang fragmen polimorfismnya. Dari hasil yang diperoleh akan dapat diambil gambaran tentang kebenaran sifat bakteri Alteromonas sp. BY9 walaupun sudah mendapat perlakuan tertentu.

\section{Keragaan genome DNA dengan amplifikasi $P C R$ dan restriksi panjang fragmen polimorfisme}

Dari hasil PCR amplifikasi genome DNA Alteromonas sp. BY-9 yang telah mendapatkan perlakuan berbeda tertera pada Gambar 5. Dari hasil tersebut nampak bahwa bakteri Alteromonas sp. BY9 yang diisolasi dan dipurifikasi dari masing-masing perlakuan, dapat diamplifikasi dengan $16 \mathrm{~S} \mathrm{r} \mathrm{DNA} \mathrm{dan}$ 
Tabel 1. Uji vitalitas benih udang yang dipelihara dengan inokulasi bakteri Alteromonas sp. BY-9 dengan perlakuan yang berbeda

Table1. Vitality test of shrimp fry reared with inoculation of Alteromonas sp. BY-9 in different treatments

\begin{tabular}{|c|c|c|c|}
\hline $\begin{array}{l}\text { Perlakuan } \\
\text { Treatment }\end{array}$ & $\begin{array}{c}\text { Alteromonas BY-9 } \\
\text { dalam mikroalga } \\
\text { Alteromonas BY-9 } \\
\text { BY-9 in microalgae }(A)\end{array}$ & $\begin{array}{c}\text { Alteromonas BY-9 } \\
\text { dalam pakan buatan } \\
\text { Alteromonas BY-9 } \\
\text { in the artificial feed }\end{array}$ & $\begin{array}{c}\text { Sel segar } \\
\text { Alteromonas BY-9 } \\
\text { Whole cell of } \\
\text { Alteromonas BY-9 }\end{array}$ \\
\hline \multicolumn{4}{|c|}{ Pengeringan pada kertas saring selama (Dried on filter paper) } \\
\hline \multicolumn{4}{|l|}{5 menit (minute) } \\
\hline Stres (stress) (\%) & 13 & 20 & 7 \\
\hline Mati (lethal) (\%) & - & - & - \\
\hline Hidup (survive) (\%) & 87 & 80 & 93 \\
\hline \multicolumn{4}{|l|}{10 menit (minute) : } \\
\hline Stres (stress) (\%) & 17 & 10 & 13 \\
\hline Mati (lethal) (\%) & 33 & 17 & 17 \\
\hline Hidup (survive) (\%) & 50 & 73 & 70 \\
\hline \multicolumn{4}{|c|}{ Perendaman dalam formaldehide (Deep in formaldehide) } \\
\hline Stres (stress) $(\%)$ & 13 & 7 & 7 \\
\hline Mati (lethal) (\%) & - & - & - \\
\hline Hidup (survive) (\%) & 87 & 93 & 93 \\
\hline \multicolumn{4}{|l|}{$150 \mathrm{mg} / \mathrm{L}:$} \\
\hline Stres (stress) $(\%)$ & 33 & 27 & 30 \\
\hline Mati (lethal) (\%) & - & - & - \\
\hline Hidup (survive) (\%) & 67 & 73 & 70 \\
\hline
\end{tabular}

memberikan fragmen tunggal. Suhu anealing $60^{\circ} \mathrm{C}$ dapat memberikan hasil yang baik dalam membentuk ikatan antara template DNA dengan primer $27 \mathrm{f}$ dan 1492 r. Dari ketiga perlakuan ternyata tidak ada perubahan berat molekul dari masing-masing isolat strain Alteromonas sp. BY-9 yaitu antara $1.500 \mathrm{bp}$.
Template DNA yang dihasilkan dari purifikasi produk amplifikasi PCR dan setelah dilakukan pemotongan dengan 3 restriksi enzim, Mbol, Hae III, dan Hha I terlihat pada Gambar 6. Terlihat bahwa Mbo I, Hae III, dan Hhal dapat memotong fragmen DNA bakteri Alteromonas sp. BY-9 secara sempurna

Tabel 2. Aktivitas enzimatik dari produk ekstra seluler Alteromonas sp. BY-9 yang mendapat perlakuan yang berbeda

Table 2. Enzymatic activity of extracelluler product of Alteromonas sp. BY-9 after treated with different methods

\begin{tabular}{|c|c|c|c|c|c|c|c|c|c|}
\hline \multirow[t]{2}{*}{$\begin{array}{c}\text { Peubah } \\
\text { Parameters }\end{array}$} & \multicolumn{3}{|c|}{$\begin{array}{c}\text { Alteromonas BY-9 } \\
\text { dalam mikroalga } \\
\text { Alteromonas BY-9 } \\
\text { BY-9 in microalgae (A) }\end{array}$} & \multicolumn{3}{|c|}{$\begin{array}{c}\text { Alteromonas BY-9 } \\
\text { dalam mikroalga } \\
\text { Alteromonas BY-9 } \\
\text { BY-9 in microalgae (A) }\end{array}$} & \multicolumn{3}{|c|}{$\begin{array}{c}\text { Alteromonas BY-9 } \\
\text { dalam mikroalga } \\
\text { Alteromonas BY-9 } \\
\text { BY-9 in microalgae (A) }\end{array}$} \\
\hline & 1 & 2 & 3 & 1 & 2 & 3 & 1 & 2 & 3 \\
\hline Gelatinase & + & + & + & + & + & + & + & + & + \\
\hline Casease & + & + & + & + & + & + & + & + & + \\
\hline Amilase & + & + & + & + & + & + & + & + & + \\
\hline Lesithinase & - & - & - & - & - & - & - & - & - \\
\hline Lipase & - & + & + & + & - & - & + & + & + \\
\hline Urease & - & - & - & - & + & - & - & - & - \\
\hline Chitinase & + & - & - & - & - & - & - & - & - \\
\hline
\end{tabular}


menjadi 3 fragmen pada Mbo I dan 4 fragmen pada Hae III dan Hhal, sedangkan pada kontrol tidak terjadi pemotongan fragmen.

Hal ini menunjukkan bahwa Alteromonas sp. BY9 walaupun telah mendapat perlakuan berbeda, yaitu diinokulasikan dan menempel pada mikroalga ataupun diinokulasikan dalam pakan mikroenkapsulasi, ternyata tidak mengalami perubahan keragaan dan berat molekul DNA. Dengan demikian, peran dan kemampuan Alteromonas sp. BY-9 sebagai biologikal kontrol dan probiotik dalam pemeliharaan larva tidak mengalami penurunan walaupun telah mendapatkan perlakuan yang berbeda. memberikan sintasan $40,44 \% ; 33,70 \%$; dan $48,98 \%$.

* Laju pertumbuhan larva dengan inokulasi Alteromonas sp. BY-9 dalam pakan mikroenkapsulasi lebih lambat 1 hari bila dibandingkan dengan 2 perlakuan lainnya, dan vitalitas larva yang tidak berbeda nyata antar perlakuan.

* Aktivitas enzimatik dari produk ekstra seluler dan keragaan DNA bakteri Alteromonas sp. BY-9 tidak mengalami perubahan walaupun telah mengalami perlakuan yang berbeda, dengan demikian peran dan kemampuannya sebagai kontrol biologi maupun probiotik dalam pemeliharaan larva udang tidak berubah pula.

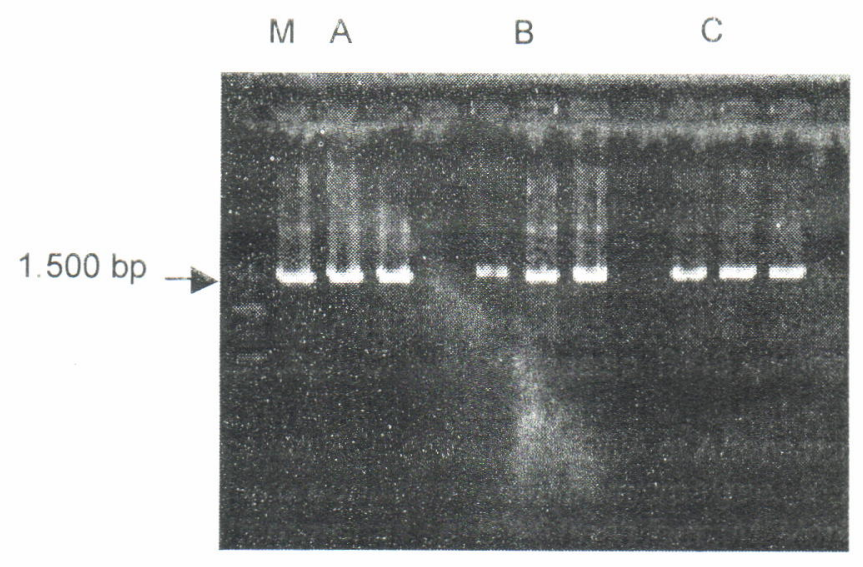

Gambar 5. Pola pita-pita tunggal genome DNA bakteri Alteromonas sp. BY-9yang mendapat perlakuan berbeda setelah melalui amplifikasi PCR (A. Alteromonas sp. BY-9 dalam mikroalga, B. Aiteromonas sp. BY-9 dalam pakan mikroenkapsulasi, C. Alteromonas sp. BY-9 sel segar, M. Marker 100 bp DNA ladder)

Figure 5. Pattern of single band amplification PCR of genomic DNA of Alteromonas sp. BY-9 after treated with different methods (A. Alteromonas $s p$. BY-9 in microalgae, B. Alteromonas sp. BY-9 in microencapsulated diet, C. Alteromonas sp. BY-9 fresh form, M. Marker 100 bp DNA ladder)

\begin{abstract}
Berdasarkan pada hasil tersebut, konsep penggunaan Alteromonas sp. BY-9 dalam pemeliharaan larva baik dalam bentuk segar maupun diinokulasikan dalam pakan alami atau pakan buatan (mikroenkapsulasi), nampaknya memberikan harapan dalam akuakultur dan merupakan alternatif dalam budi daya udang berkelanjutan secara industrial dan berwawasan lingkungan tanpa penggunaan antibiotik. Selain itu penggunaan yang sederhana dan mudah dari Alteromonas sp. BY-9 ini akan sangat diharapkan dari praktisi hatcheri.
\end{abstract}

\section{KESIMPULAN DAN SARAN}

\section{Kesimpulan}

* Aplikasi bakteri Alteromonas sp. BY-9 melalui inokulasi dalam pakan alami, pakan buatan mikroenkapsulasi maupun sel segar masing-masing

\section{Saran}

Disarankan agar dilakukan penerapan metode dan proses pembuatan pakan mikroenkapsulasi dengan menggunakan suhu yang dapat ditoleransi oleh bakteri Alteromonas sp. BY-9, agar tidak terjadi mortalitas setelah diaplikasikan dalam media pemeliharaan larva.

\section{UCAPAN TERIMA KASIH}

Dengan selesainya penelitian ini kami mengucapkan terima kasih atas bantuan dan kerja sama yang baik dari para teknisi di Laboratorium Bioteknologi dan Hatcheri Udang. Terima kasih pula diucapkan pada project JICA (Japan international Cooperation Agency) ATA 379, AIMS (Australian Institute of Marine Science) dan CSIRO (Commonwealth Scientific and Industrial Research Organization) yang telah membantu dalam penyediaan peralatan. Penelitian ini dilaksana-kan atas biaya dari APBN Indonesia tahun anggaran 1999-2000. 


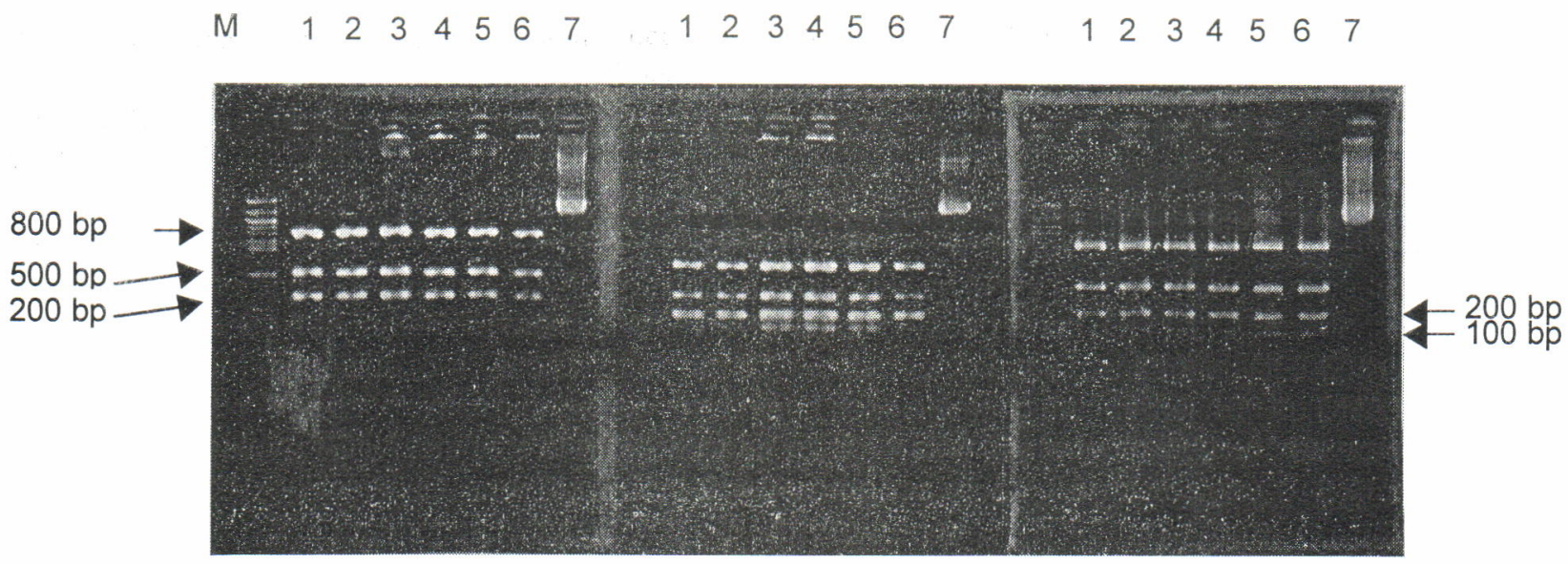

Gambar 6. Pemotongan template DNA dari bakteri Alteromonas sp. BY-9 setelah mendapat perlakuan yang berbeda dengan enzim restriksi Mbo I (A), Hae III (B), dan Hha I (C) (1-2: Alteromonas sp. BY-9 dalam mikroalga, 3-4: Alteromonas sp. BY-9 dalam pakan mikroenkapsulasi, 5-6: Alteromonas sp. BY-9 segar, 7: Alteromonas sp. BY-9 yang tidak dipotong, M: Marker 100 bp DNA ladder)

Figure 6. Digestion of DNA template of Alteromonas $s p$. BY-9 after treated with different restriction enzyme Mbo I (A), Hae III (B), and Hha I (C) (1-2: Alteromonas sp. BY-9 in microalgae, 3-4: Alteromonas sp. BY-9 in microencapsulated diet, 5-6: Alteromonas sp. BY-9 fresh form, 7: Undigestion of Alteromonas sp. BY-9, M: Marker 100 bp DNA ladder)

\section{DAFTAR PUSTAKA}

Ditjenkan. 1999. Program Pengembangan Budidaya Udang Nasional 250.000 ha dalam Rangka Pencapaian Devisa Produksi Perikanan US\$ 8 Milyard. Direktorat Jendral Perikanan (in press)

Douillet, P.A and C.J. Langdon. 1994. Use of a probiotic for culture of larvae of the Pacific oyster (Crassostrea gigas Thunberg). Aquaculture 119: 25--40.

Fukami, K., A. Yuzawa, T. Nishijima, and Y. Hata. 1992. Isolation and properties of bacterium inhibiting the growth of Gymnodinium nagasakiense. Nippon Suisan Gakkaishi 58(6): 1073--1.077.

Fuller, R. 1986. Probiotics, J. Appl. Bacteriol. Suppl. 5-75.

Gibson, L.F., J. Woodworth, and A.M. George. 1998. Probiotic activity of Aeromonas media on the Pasific oyster Crassostrea gigas, when challenged with Vibrio tubiashi. Aquaculture 169:111--120.

Giri, N.A., M. Marzuqi, Jufri, dan C. Kuma. 1992. Studi pendahuluan pengaruh beberapa sumber protein terhadap perkembangan dan kelangsungan hidup larva udang windu Penaeus monodon. J. Penel. Budidaya Pantai 8(3): 57--66.

Haryanti. 1997. Preliminary studi on the use of bacteria as biocontrol for culture of microalgae Chaetoceros ceratosporum. In Darussamin A., I.P. Kompiang, S. Moeljopawiro (Eds.). Current status of agricultural biotechnology in Indonesia. Proceedings second Conference on Agricultural Biotechnology, Jakarta, 13--15 June 1995. p. 563--569.

Haryanti, S. Lante, and S. Tsumura.1997a. Studi pendahuluan penggunaan bakteri BY-9 sebagai probiotik dalam pemeliharaan larva udang windu Penaeus monodon. Jurnal Penelitian Perikanan Indonesia III(1): 44--52
Haryanti, K. Sugama, S. Lante, and S. Tsumura. 1997b. Teknik biokontrol dalam pembenihan udang Penaeus monodon. Prosiding Regional Hasil-hasil Penelitian Berbasis Perikanan, Peternakan, Sistim Usaha Tani di Kawasan Timur Indonesia, Kupang 28--30 Juli 1997.

Haryanti and K. Sugama. 1998. Diseases problem and use of bacteria as biocontrol agent for larval rearing of Penaeus monodon in Indonesia. In Huai-Shu Xu (eds.). Proceeding of the Regional Workshop on Disease Problems of Shrimp Culture Industry in the Asian Region and Technology of Shrimp Disease Control. October 9-14, 1998 Qingdao, China. p. 1--9. Haryanti, K. Sugama, and S. Tsumura. 1998. Use of BY9 as a probiotic agent in the larval rearing of Penaeus monodon. In T.W. Flegel (Eds.). Advances in shrimp biotechnology. Proceedings to the Special Session on Shrimp Biotechnology, $5^{\text {th }}$ Asian Fisheries Forum, 11-14 November 1998, Chiangmai, Thailand. p. 183-185 .

Moriarty, D.J.W. 1998. Control of luminous Vibrio species in penaeid aquaculture ponds. Aquaculture 164: 351---358.

Nakamura, A., K.G. Takahashi, and K. Mori. 1999. Vibriostatic bacteria isolated from rearing seawater of oyster broodstock: Potenciality as biocontrol agents for vibriosis in oyster larvae. Fish Pathology 34(3): 139--144

Nogami, K. and M. Maeda. 1992. Bacteria as biocontrol agent for rearing larva of the crab, Portunus trituberculatus. Canadian Journal of Fisheries and Aquatic Science 49(11): 2373--2376.

Rengpipat, S., W. Phianphak, S. Piyatiratitivorakul, and P. Menasveta. 1998. Effects of a probiotic bacterium 
on black tiger shrimp Penaeus monodon survival and growth. Aquaculture 167: 310--313.

Riquelm, C.E., K. Fukami, and Y. Ishida.1988. Effect of bacteria on the growth of marine diatom, Asterionella glacialis. Bull. Japan. Soc. Microbiol. Ecol. 3: 29--34.

Sugita, H., Y. Hirose, N. Matsuo, and Y. Deguchi. 1998. Production of the antibacterial substance by Bacillus sp. strain NM 12, an intestinal bacterium of Japanese coastal fish. Aquaculture 165: 269--280.

Sukoso, K. Iwamoto, T. Sakata, and T. Yoshikawa. 1998 Characteristic of filamentous bacteria co-existing with some marine microalgae. Fisheries Science 64(1): 65-70.

Uma, A. 1999. Feed Probiotics for Sustainable Aquaculture. Asian Aquaculture, Aquaculture Department, SEAFDEC, Philippines XXI(2): 13--15.

Xu Bing, J. Weishang, and X. Huai Shu. 1996. Pathogens and pathogenicity to Penaeus orientalis Kishinouye. Selected Paper on Marine Biotechnology. College of Marine Life Science, Ocean University of Qingdao. p. 229--239. 